\title{
Ghana's Return to Constitutional Rule under the Provisional National Defence Council (PNDC)
}

\author{
By Joseph R.A. Ayee
}

\section{Formulation of Transition Programme}

Ghana's transition to constitutional rule under the Provisional National Defence Council (PNDC) began slowly with the establishment of the National Commission for Democracy (NCD) by PNDC (Establishment) Proclamation of 1981. In 1982, PNDC Law 42, Section 32 , elaborated on the function of the NCD to include, inter alia, the following: (a) to disseminate within the society awareness of the objectives of the revolutionary transformation of the society being embarked upon by the PNDC in the interest of real democracy; (b) to assess for the information of the Government the limitations to the achievement of true democracy arising from the existing inequalities between different strata of the population and make recommendations for redressing these inequalities; (c) to formulate for the consideration of Government a programme for a more effective realization of a true democracy in Ghana. ${ }^{1}$ In other words, the NCD was not only established to design a "true democracy", but also "to take into consideration our tradition, history and culture ... certain sociocultural values, such as consultation, voluntarism, participation, consensus and self-reliance which we cherish as a people but which we have failed to integrate into the political order." ${ }^{2}$ The functions of the Commission were further consolidated in 1988 by PNDC Law 208.

The establishment of the NCD did not change the caution and hesitation with which the PNDC approached the transition to constitutional rule. The regime still asked its rhetorical question, "hand over to whom?" and continued to talk of creating the necessary conditions for the "redundancy" or "withering away" of the PNDC. ${ }^{3}$

1 Republic of Ghana, PNDCL 42: Provisional National Defence Council (Establishment) Proclamation (Supplementary and Consequential Provisions) Law (Accra: Ghana Publishing Corporation, 1982), Section 32.

Republic of Ghana, "The Search for True Democracy in Ghana", Accra, Information Services Department, n.d., pp. 10-11.

3 Brigadier J. Nunoo-Mensah, the first Chief of Defence Staff when asked at a press conference in April 1982 as to when the PNDC will return the country to constitutional rule, replied: "Hand over to whom?" See Ghanaian Times, 4 April 1982. 
From 1984 to 1978 , the NCD, in pursuance of its functions, invited the public to submit papers/memoranda on the future form of government for the country. Seminars, symposia and durbars were held by the NCD and other government functionaries with the public to discuss the "effective realization of a true democracy in Ghana" ${ }^{4}$. The result of these led to the launching of the "Blue Block" - the document of the "Creation of District Political Authority and Modalities for District Level Elections in Ghana" by the number two man, Justice D.F. Annan, on 1 July 1987 at Kumasi. On 11 November 1988, PNDC Law 207, the Local Government Law which concretized the ideals enshrined in the "Blue Block", was promulgated. This culminated in the holding of the district assemblies elections between December 1988 and February 1989 and the subsequent establishment of the District Assemblies (DAs).

The establishment of the DAs was regarded by the PNDC as an important step in the government's programme of "evolving national political authority through a democratic process" ${ }^{5}$. In this connection the NCD was also charged with the responsibility of "working out the steps in the programme and also the relationships between the District Assemblies and ultimate national political institutions" ${ }^{6}$. Consequently, the NCD in collaboration with the Ministries of Local Government and Information organized a series of seminars in all the ten regional capitals from 5 July to 9 July 1990 on "District Assemblies and the Evolving Democratic Process" 7 . The main reason for holding the seminars was to "invite the views of the public on what next after the District Assemblies, in fulfilment of the PNDC's commitment to involve the people in working out programmes for the evolution of the country's democratic process beyond the district level" 8 . However, as they turned out, the regional fora and consultations, far from being a debate on the form of political system that the country needed, rather became a carefully orchestrated plan to foist a no-party system of government under the tutelage of Rawlings on the country. The debates, often presided over by PNDC officials and sympathisers, were not only used to canvass positions known to be favoured by the government but also a platform to attack the evils of the multiparty system, the failure of past politicians and the sanctity of the coups of 4 June 1979 and 31 December $1981 .{ }^{9}$ What made the fora even more suspect to Ghanaians was the fact that most people had no idea of the sort of democratic process that was being ushered in. The

4

Republic of Ghana, Evolving a True Democracy: Summary of NCD's Work Towards the Establishment of a New Democratic Order, Tema, Ghana Publishing Corporation, 1991, p. ix.

5 Republic of Ghana, District Political Authority and Modalities for District Level Elections, Tema, Ghana Publishing Corporation, 1987, pp. 1-2.

6 Ibid.

7 Republic of Ghana, Evolving a True Democracy, op. cit., p. $x$.

8 Ibid.

9 See E. Gyimah-Boadi, Tensions in Ghana's Transition to Constitutional Rule, in: K.A. Ninsin / F.K. Drah (eds.), Ghana's Transition to Constitutional Rule, Accra 1991, p. 36. 
address of the chairman of the PNDC, Rawlings, on 5 July 1990 at Sunyani during the first seminar, did not indicate that the seminars were meant to discuss proposals for the return of the country to constitutional rule. The chairrnan's address regarded the seminars as an evaluation of the DAs. Seen in this way, the seminars "metamorphosed into a debate on the future governance of this country and it was due to external and internal pressures as well as the government's desire to give its end-product some form of respectability." 10

Originally the seminars were restricted to only members of the District assemblies (DAs) and invited bodies and so-called progressive organs, like the 31 December Women's Movement, the Committees for the Defence of the Revolution and the June 4 Movement. This, plus the virtually identical nature of the constitutional proposals made by all the DAs, provided clear pieces of evidence about the intention of the PNDC government to perpetuate itself in power. The DAs were calling for a no-party system of government for the election of members of the national parliament by the DAs, a third of whose members were nominated by the PNDC. And for the election of Rawlings as Head of State.

In order to expose the "hidden agenda" of the PNDC to call for a "proper open" national debate and to work for the restoration of multi-party democracy and civilian rule in Ghana, the Movement for Freedom and Justice (MFJ) was formed on 1 August 1990 under the chairmanship of Professor Adu Boahen, who later became the presidential candidate of the New Patriotic Party (NPP) in the November 1992 presidential elections. The demands of the MFJ included the release of all political detainees, the granting of an unconditional amnesty to all exiles, the drawing up of a constitutional timetable, and the lifting of the ban on party politics. To create a congenial atmosphere for the debate about the future political system for the country, the MFJ and other pro-democracy forces such as the Bar Association, the National Union of Ghana Students (NUGS), the Catholic Bishop Conference and the Christian Council demanded the repeal of all repressive laws, especially the Preventive Custody Law (PNDC Law 4), the Habeas Corpus Amendment Law (PNDC Law 91), the Newspaper Licensing Law (PNDC Law 211) and the sections of the Public Tribunal Law (PNDC Law 78) which deal with execution for political offences. Above all, the prodemocracy forces stressed that the issue as to whether the country should have a multi-party or a no-party system of government in the future should be decided "through a genuine national debate culminating in a national referendum organized by an independent body" ${ }^{11}$.

10

Kwame Boafo-Arthur, Prelude to Constitutional Rule: An assessment of the Process, in: $K . A$. Ninsin /F.K. Drah (eds.), Ghana's Transition to Constitutional Rule, Accra 1991, p. 46.

11

A. Adu Boahen, Speaking at the symposium on Constitutional Process and Referendum organized by the Greater Accra Branch of the Ghana Bar Association, at the Law School, Accra, on 24 July 1991; see The Pioneer, 1 August, 1991. 
Despite this pressure on the PNDC. The government seemed reluctant and hesitant to meet the demands of the pro-democracy forces. As if he had his own political agenda, J.J. Rawlings, in his 1 January 1991 New Year Broadcast to the nation, asked the NCD to expedite work on its report in the regional fora and to present it at the end of March 1991 to enable the

"PNDC to convene a broad-based national consultative body which would use the report as well as the 1957, 1960, 1969 and 1979 constitutions, as the basis for further consultations and discussions on the form and content of the future constitution." ${ }^{12}$

In March, 1991 the NCD submitted its report on the regional fora to the PNDC. The NCD report which was accepted by the PNDC noted that most Ghanaians were unequivocably in favour of a multi-party system of government:

"The general opinion was that the generality of the population is not against political parties as an ideal instrument that may give the fullest expression to the freedom of association. But the practice of political parties ... must eschew some of the unacceptable features of party politics such as when political parties become corporate vehicles of investment which must be recouped." ${ }^{13}$

In spite of this, GBC/TV started a series of interviews on whether Ghanaians wanted a return to party politics or to "no-party" system. The fears of those who believed in the multi-party system were not allayed by the fact that most of the people interviewed on GBC/TV opposed the multi-party system. Some people's fears were further exacerbated when the Head of State, J.J. Rawlings, in an interview with a reporter of the People's Daily Graphic just before he left for the summit of the Organization of African Unity (OAU) held in Abuja, Nigeria, in June 1991, stated quite categorically that he did not personally believe in the multi-party system, but that since it was a decision of the intire PNDC, he stood by it. $^{14}$ This pronouncement created doubt of his sincerity to return the country to constitutional rule.

To summarize, it is possible to suggest that the formulation of the programme to return the country to constitutional rule had not only been tendentious and half-hearted, but it also gave a clear indication that the PNDC failed to take "advantage of its longevity in order to refine a clear concept of democracy or to otherwise promote democratic practices" ${ }^{15}$.

J.J. Rawlings, New Year Broadcast to the Nation, 1 January 1991. See the People's Daily Graphic, 2 January 1991, and Republic of Ghana, Evolving a True Democracy, op. cit., p. x.

13 See People's Daily Graphic, 6 June 1991, p. 1.

14 Ibid.

15 Naomi Chazan, Planning Democracy in Africa: A Comparative Perspective on Nigeria and Ghana, in: Policy Science, Vol. 22, 1989, p. 345. 


\section{Implementation of Transition Programme}

Although the government accepted the report of the NCD to return the country to constitutional rule, no clear-cut timetable ${ }^{16}$ was spelt out for the transition (see Table 1). The government's response to the NCD report was to establish in May 1991 a Committee of Experts to formulate constitutional proposals under PNDC Law 252. The Committee, under Dr. S.K.B. Asante, was to submit proposals to the PNDC on the proposed constitution and to assist the Consultative Assembly both in the formulation of the draft constitution and in the technical aspects of the work of the Consultative Assembly (CA). The Committee was also to take into account in its deliberations the NCD's report, the abrogated Constitutions of 1957, 1960, 1969 and 1979 and any other constitutions. ${ }^{17}$

The establishment of the Committee of Experts was severely criticised on the grounds that the appointment of the chairman and the eight members of the Committee was an attempt to pack it to produce or, as it was generally suspected, to merely rubber-stamp proposals submitted to it by the PNDC. Although there is little evidence to show that the Committee was influenced on its work, certain proposals like the ones on the "split" executive, citizenship, decentralization and political parties, were believed to have been influenced by the PNDC, especially so when the proposals were forwarded directly to the PNDC and not the Consultative Assembly. Another issue which raised eyebrows was that the Committee of Experts was empowered to assist the Consultative Assembly in the formulation of the draft constitution - a move seen as an attempt by the PNDC to increase the number of its sympathisers in the Consultative Assembly. The Committee of Experts submitted its report to the Government on 31 July 1991.

The next institution created to work towards constitutional rule was the Consultative Assembly established under PNDC Law 253 of 1991. It was to prepare a Draft Constitution for Ghana using:

(i) the proposals for the future Constitution of Ghana submitted to it by the PNDC;

(ii) the abrogated Ghanaian Constitutions of 1957, 1960, 1969 and 1979 and other Constitutions;

(iii) the Report of the National Commission for Democracy presented to the PNDC entitled "Evolving a True Democracy", and to submit to the PNDC not later than 31 December 1991 the Draft Constitution for the administration of Ghana. ${ }^{18}$

The timetable for the transition to constitutional rule in Table 1 was not a clearly laid out and publicised one. The timetable was therefore compiled by the author.

Republic of Ghana, Committee of Experts (Constitution) Law, PNDC Law 252, Tema, Ghana Publishing Corporation, 1991.

18 Republic of Ghana, Consultative Assembly Law, Tema, Ghana Publishing Corporation, 1991. 
Like the Committee of Experts, the functions and composition of the Consultative Assembly came under attack. First, it seemed inappropriate to set up a body to prepare a Constitution for Ghana and call it merely "consultative". This was interpreted as an attempt by the PNDC - an unelected and unrepresentative body - to have itself the final say on the nature of the constitution of the country.

The second objection related to the composition of the Consultative Assembly (CA). The composition of the Assembly revealed a "disorganized" attempt to pack it with progovernment elements to merely rubber-stamp those proposals that would be placed before it by the PNDC. PNDC Law 253 that established the CA stipulated that it should consist of 117 persons elected by the District Assemblies, 121 persons elected from 62 "identifiable bodies" listed under the Second Schedule of the Law, and not more than 22 persons appointed by the PNDC. It should be pointed out that a third of the membership of the DAs was appointed by the PNDC while it was likely that a majority, if not all of the 117 members elected by the DAs may be said to be supporters and sympathisers of the PNDC. Also nowhere in PNDC Law 207 creating the DAs were they assigned constitution-making functions nor envisaged as electoral bodies. Furthermore, it became clear that during the regional seminars virtually all the DAs were opposed to the multi-party system. It was widely believed that the only justification for giving the DAs the huge 117 representation was merely to help rubber-stamp whatever the PNDC put before the CA.

A third criticism had to do with the 62 bodies listed under the Second Schedule to elect persons to the Assembly. The definition of "identifiable" bodies was not only "fuzzy" but almost bizarre. ${ }^{19}$ While bodies like the Butchers Association, Hairdressers and the Bakers Associations were included, others like the Ghana Institute of Management, the Ghana Veterinary Medical Practitioners, the Public Relations Association of Ghana and the Hoteliers Association were excluded. The result was that over twenty such associations queried their exclusion and applied for representation in the CA. This was turned down with no official reasons being assigned.

A related criticism was the over-representation of some bodies in the CA. For instance, the Armed Forces with a total number of 20,000 had eight seats while the Police Service with a workforce of 80,000 were given only two seats. Again, it seemed manipulative to give the Committees for the Defence of the Revolution (CDRs) ten seats and the Butchers Association one seat - bodies that never expressed any interest in a return to constitutional rule, even though they never lacked the chance to do so - while the 80,000 strong Ghana National Association of Teachers (GNAT) had two seats and the Bar Association, the Christian Council, the National Union of Ghana Students (NUGS) and the University 
Teachers Association of Ghana - bodies which had made persistent demands for constitutional rule - had one seat each.

A final criticism levelled against the Consultative Assembly was that it was not only packed but seemed also to have been gagged. This was evident from Section 13 of PNDC Law 253 establishing the CA which provided that:

"Nothing in this section shall be deemed to relieve any person from any action or proceedings ... in respect of anything said or done by him against the Head of State and Chairman of the Council or any member of the Council of a PNDC Secretary." 20

The Ghana Bar Association (GBA) and the MFJ, the two institutions that spearheaded the criticism against the PNDC transition programme, pointed out that the refusal to accord unlimited immunity to the members of the CA was a flagrant departure from the established constitutional and parliamentary tradition of Ghana "which would have the effect of gagging all but the most daring members" ${ }^{21}$. These fears may have been confirmed when a "gagged" Assembly inserted the Transitional Provisions in the Fourth Republican Constitution that seek to indemnify the Chairman and other members of the PNDC and its other appointees from prosecution by any court or tribunal in Ghana for any act or omission during the administration of the PNDC. This indemnity clause which was handed down from the PNDC seems to defeat the tenets of accountability and probity preached under the PNDC. As a result of the serious misgivings about the composition and powers of the CA, the GBA and NUGS boycotted it. Even though some assembly members asserted that their deliberations were not interfered with excessively by the PNDC, others referred to manipulation sand interference from the PNDC. ${ }^{22}$

The inauguration of the CA, on 26 August 1991 by Rawlings, was regarded as part of the PNDC's so-called methodical march towards democratic rule:

"The exercise which you begin today ... represents the final stage of the processes which are phasing out the provisional structure, in order to ensure the continuity of the advances which have been made. ... Any observer who has watched or participated in events in this country over the past nine and a half years will have witnessed a consistent pattern, a sequence moving towards the establishment of a just and lasting democratic system embodying the will of the people. This Consultative 
Assembly is the next logical step in this process which began on 31 December $1981^{23}$

This speech must be seen as an attempt to expedite the process to constitutional rule due to mounting pressures from within Ghana and the international donor agencies. The CA presented its report to the government not on the scheduled 31 December 1991 but rather on 31 March 1992 due to the volume of work it had to contend with. It recommended an American style executive presidential system of government for the country. Before the presentation of the report, an Interim National Electoral Commission (INEC) under the chairmanship of Justice Josiah Ofori-Boateng, an Appeal Court Judge, was established on 11 November 1991 to conduct the referendum on the constitution and the presidential and parliamentary elections scheduled for November and December 1992. On 5 March 1992 in a nation-wide broadcast to the nation to mark the $35^{\text {th }}$ Independence Anniversary, Rawlings, for the very first time, announced a timetable for transition to constitutional rule with the promise that "this year (1992) will see the culmination of a process towards establishing a new constitutional order". ${ }^{24} \mathrm{He}$ also extolled the virtue of the PNDC's approach to constitutional rule because:

"...for the first time in the history of our nation, constitution-making has also involved honest simple men and women from all walks of life. From the onset of the 31st December Revolution, our conviction was that true democracy required the meaningful participation of all Ghanaians in the structures and practice of government. The steps we have taken so far in this process do attest to this conviction. Consultation and discussion in public fora around the country with the view to attaining national consensus have been our approach." ${ }^{25}$

Rawlings then went on to outline a timetable for the transition programme: a referendum on 28 April 1992, the lifting of the ban on politics from 18 May 1992, the holding of presidential and parliamentary elections on 3 November 1992 and 8 December 1992 respectively. The inauguration of the Fourth Republic was to take place on 7 January $1993{ }^{26}$ This timetable, with the exception of the parliamentary elections which was postponed to 29 December 1992, for reasons we will outline later, was faithfully adhered to.

Republic of Ghana, "Constitution Must be Born by Truth and Integrity", Address by the Head of State and chairman of the PNDC on the occasion of the inauguration of the Consultative Assembly in Accra on 26 August 1991; Accra, Information Services Department, 1991, p. 4.

Republic of Ghana, "Guidelines for Ghana's Return to Constitutional Rule", Nationwide broadcast by the Head of State on the eve of the 35th Independence Anniversary, 5 March 1992, Accra, Information Services Department, 1992, p. 2.

Ibid. pp. 2-3

26

Ibid. pp. 2-4. 
The holding of the referendum was a contentious issue. Rawlings provided four reasons. First, it was considered to be an exercise not only to give the Constitution the "stamp of approval" but also elicit the "readiness of Ghanaians to protect it". ${ }^{27}$ Second, the referendum was supposed to educate Ghanaians about the provisions in the draft constitution, and this "must not be seen as an exercise in division but as the creation of a national consensus in line with our traditional principle of arriving at a consensus which binds even the dissenter". ${ }^{28}$ Third, approval of a Constitution by referendum is the thing in vogue all over the world and was used in some countries in Africa and Eastern Europe. Fourthly, the holding of the referendum was considered an innovation in the constitutional history of the country:

"All our previous constitutions have affirmed the sovereignty of the people as a supreme principle, but none has observed that principle with the actual direct endorsement of the people." 29

The opposition forces led by the MFJ and the GBA saw the holding of the referendum as a dubious and questionable aspect of the constitutional process on three grounds. First, they did not see the wisdom in submitting a complex document like the constitution dealing with such a variety of topics and having so many sections for approval on the basis of "Yes" or "No". Second, should the outcome of the referendum be negative, it was likely the PNDC would use it as an excuse to prolong its rule. Third was the position taken by Rawlings himself on the question of the referendum. When he was asked by Africa Report for his view on the call of the opposition groups for a referendum to decide the simple question of whether there should be a no-party or a multi-party system during the national debate between July and December 1990, Rawlings replied:

"A referendum, by its nature, must be a yes and no affair, or must deal with a very limited number of simple options. I fail to see how the complex options presently before Ghanaians can be reduced to such terms. Are we prepared for the consequences of this oversimplification? If we have to be fair and comprehensive with our search for democracy, we were to subject each issue before us to a separate referendum, how long will it take us to be there?"30

It was the stand of the opposition forces that if the simple question of whether there should be a no-party or a multi-party system of government should not be decided in a referendum,

Ibid. p. 3.

Ibid. p. 3.

29

Ibid. p. 3.

30 Africa Report, June 1991, pp. 3-4. 
then they had cause to be suspicious of the wish of the PNDC regime to decide the issue of the whole constitution in a referendum.

Despite the protests the government went ahead with the referendum on 28 April 1992. The constitution was overwhelmingly endorsed by $92 \%$ of the $3,680,973$ voters who turned up. $^{32}$ Thereafter the ban on politics was lifted with the promulgation of the Political Parties Law, PNDC Law 281 of 18 May 1992. Two requirements on the Law were contested at the Supreme Court by a group of opposition leaders who sought, without success, to get the court to issue and injunction to restrain INEC from executing the Law. The first controversial requirement was the pegging of the amount of individual contribution to party funds at 200,000 cedis. The opposition groups claimed that the amount did not only take into account the cost of living and the inflation and exchange rate in the country but also an attempt by the PNDC to starve the opposition of funds. The Law was subsequently amended by the PNDC to empower the INEC to set the limit of individual funding. The amount was raised to one million cedis after consultation with potential party leaders. This again was not acceptable to most political groups who suggested levels of contributions ranging from 100 million cedis to 20 million cedis. ${ }^{33}$ This suggestion was, however, rejected by INEC which stuck to the one million cedis individual contribution. Second, the Law stipulates that no name, symbol, colour or slogan could be used which identified parties with any of the parties which had contested previous Ghanaian elections, for example, the Convention People's Party (CPP) and the Progress Party (PP). This requirement was also inserted in the 1979 Political Parties Decree (SMC Decree 229). The enforcement of the stipulation seemed to be a setback to the Busia-Danquah and Nkrumahist groups who wanted to use old party symbols because the PNDC by then had also associated itself with the Eagle Club, which had wanted to use the eagle - the nation's symbol. Its familiarity to the electorate was considered to be an advantage to the PNDC.

\section{The November 3, 1992 Presidential Elections}

When the ban on politics was lifted, seven political parties emerged to campaign for both presidential and parliamentary elections. The parties could be divided superficially into two groups: viz; pro-Rawlings parties - the National Democratic Congress (NCD), the National Convention Party (NCP) and the Every Ghanaian Living Everywhere (Egle) Party; and anti-Rawlings parties, the New Patriotic Party (NPP) led by Adu Boahen, which belonged

Boahen, Speaking at the Symposium on Constitutional Process and Referendum, op. cit. West Africa, 11-17 May 1992, p. 809.

33 See J.R.A. Ayee, Financing Political Parties in Ghana: An Exploratory Study, in: K.A. Ninsin / F.K. Drah (eds.), Political Parties and Democracy in Ghana's Fourth Republic, Accra 1993, pp. 250-251. 
to the Danquah-Busia tradition, and three parties with Nkrumahist inclinations - the People's National Convention (PNC) led by former President Hilla Limann, Lt. General (Rtd) Emmanuel Erskine's People's Heritage Party (PHP) and multi-millionaire businessman Kwabena Darko's National Independence Party (NIP). The NDC, NCP and Egle Party had J.J. Rawlings as their presidential candidate. This arrangement may have given Rawlings an edge over the opposition parties since they remained fragmented and failed to forge a common front to articulate a constructive vision of a future Ghana. It must be pointed out that the parties were superficially, but fundamentally the re-emergence of the traditional two-camp structure.

Rawlings had a head-stock and continuing advantages over his opponents in the presidential elections because of his incumbency. He controlled and manipulated the agenda and the timetable leading up to the elections. In the words of the International Foundation for Electoral Systems that monitored the 1992 referendum, Rawlings and the PNDC "remain the obvious source of political initiatives, retaining their claim to the last word in decision that affect the forward movement of Ghanaian policy" ${ }^{34}$. Rawlings used state resources at his disposal for his campaign - money, government vehicles, helicopters, the press - while the other parties, starved of funds and resources, could only complain bitterly to INEC about the disparity in resources before they were allocated a limited number of vehicles for their campaigns. The NPP, for instance, had 12 vehicles while PHP had 6. The distribution was done by INEC based on the strength of the parties across the country. Rawlings and his PNDC dominated the state-owned media and influenced the way news and features should be disseminated. Although the ban on politics was lifted on 18 May, 1992, Rawlings had for long been campaigning even though he did not declare his intention to run the elections until the date for official nominations on 30 September, $1992 .^{35}$

The refusal of the PNDC to open up the voters register to those who failed to register for the district assemblies elections of $1988 / 89$ or for the partially updated register in 1991 meant that the opponents of the regime were left without a chance to participate in the elections. The deficiencies in the voters' register used for the elections was a source of worry an concern for the team of the International Foundation of Electoral Systems:

"It is imperative that a re-registration of all eligible voters be undertaken as quickly as possible. The quality of the current registration list is the most pressing problem, one that directly affects the success of the transition. The list suffers from deficien-

Laurie Cooper / Fred Hayward / Anthony Lee, Ghana: A Pre-Election Assessment Report, June 1, 1992, Washington, D.C., 1992, p. 1.

See Richard Jeffries / Clare Thomas, The Ghanaian Elections of 1992, in: African Affairs, Vol. 92, No. 368, July 1993, pp. 331-366. See also David Abdulai, Rawlings "Wins" Ghana's Presidential Elections: Establishing a New Constitutional Order, in: Africa Today 39, 4th Quarter 1992, p. 70. 
cies such as multiple entries, inconsistent name order, failure to record corrections, and ghost entries. No attempt has been made to purge the list of deceased voters." ${ }^{36}$

But Rawlings' greatest advantage, reminiscent of Busia's victory in 1969, was the fact that he had been in power, and not for only three years, but over a decade and had built a support base in the CDR's, the DAs, the 31 December Women's Movement and the Mobisquads who openly campaigned for him. These incumbency advantages, it must be pointed out, are enjoyed all over the world, but their effect in the Ghanaian context may have proved decisive in influencing the results of the elections. Although well-known to the opposition parties, these advantages were taken so lightly by the opposition that they spelt their doom during the presidential elections.

No sharp differences on issues separated the manifestos of the contesting parties during the campaign period. All the parties espoused the supremacy of private enterprise and the free market economy and the continuation of the Structural Adjustment Programme. All made promises on health, education, employment and the upliftment of the standards of living of Ghanaians. Rawlings preached the message of "continuity" of the PNDC's policies while the opposition parties campaigned for change of personnel and some implied revenge.

It is pertinent for us here to pause and ask why after eleven years in office Rawlings decided to contest the elections: The main reason was that given the revenge threats by some members of the oppositions, Rawlings and the PNDC thought it had to contest the elections not only to ensure "continuity" of their policies and seek legitimacy but also safeguard the very lives of some officials and supporters.

As the country approached the elections, there were indications that the elections would be a straight fight between Rawlings of the NDC and Adu Boahen of the NPP. This again was a manifestation of the two-camp factor. The CPP in its many forms drifted essentially to Rawlings. The Rawlings campaigns drew larger crowds than the opposition presidential candidates, particularly in the rural areas. The press also became highly polarised. The state press supported Rawlings and gave the polls to Rawlings and his NDC since they have "support in the rural communities who see the extension of electricity, the provision of portable water, good roads as a way of improving their conditions of living" ${ }^{37}$. The private press, on the other hand, was generally anti-Rawlings and heavily tipped Adu Boahen to carry the day. For instance, in a front page headline of the Ghanaian Chronicle of 2 November 1992 the paper wrote: "So long Jerry; Let's give him a hand, let's try and forgive, but let's save him from the Castle (the seat of government). ${ }^{38}$ Even the renowned

36

37

Cooper / Hayward / Lee, op. cit., p. 45.

The Mirror (Accra), 31 October 1992, p. 3

38 The Ghanaian Chronicle, 2 November 1992, p. 1. 
Ghanaian astrologer, Dr. Baldwin Baddoo, predicted that Boahen had an edge over Rawlings:

"... But if I have to be (guided) by the political history of this country, the benefit of the doubt should go to the New Patriotic Party. This assumption will be confirmed or rejected by the (election) result ..." 39

Indeed, the assumption of Baddoo was not only rejected by the results of the election but it came as a surprise to those who believed that the NPP's Adu Boahen would become the first president of the Fourth Republic. The results of the elections showed that Rawlings had won a clear majority of $58.3 \%$ of the votes cast in the whole country as against Adu Boahen's $30.4 \%$. The results negated the need for a run-off election. Rawlings did very well in the rural areas as well as in most parts of the country (93.3\% in the Volta Region; $66.5 \%$ and $60.7 \%$ in Western and Central Regions respectively; $61.9 \%$ in Brong Ahafo Region and $63.2 \%$ in the Northern Region). The only region where Rawlings fared rather poorly was in the NPP stronghold, Ashanti Region, where he polled $32.9 \%$ of the votes as against Adu Boahen's $60.5 \%$. The outcome of the election was a personal victory for Rawlings and a humiliating and devastating one for Adu Boahen. For Rawlings, despite the austerity measures pursued under Structural Adjustment Programme (SAP), he was able to leave behind an unpopular and repressive past to put on the cloak of being the first leader of an African military regime to win a competitive multi-party election.

How does one explain the success of Rawlings at the polls? The first factor is the incumbency advantages to which we have referred. The second factor is the lack of unity among the opposition. The opposition failed to put up a single candidate against Rawlings. The disarray within the Nkrumah family helped Rawlings and the NDC a great deal. The threeway split among those who claimed to be the followers of Nkrumah meant a lack of focus for those who would normally vote for an Nkrumahist party. More important was the success of the NDC (and its allies) at presenting itself as the party of Kwame Nkrumah. In the final lap towards the elections, there were campaign advertisements in the press to drive the point home. Rawlings visited Nkroful, Nkrumah's birthplace, where he commissioned his nearly forgotten tomb twenty years after his death. The fact that Rawlings benefited from the split in the Nkrumahist parties was not doubtful. What will be doubted and debated in the forthcoming years is whether the split within the Nkrumahist party was due to Rawlings' "political savvy or chicanery" ${ }^{40}$. A third reason is the ability of Rawlings and the PNDC to deliver the goods by providing roads, electricity and water in the rural areas. The provision of these amenities in the rural areas despite the corresponding hardships

Baldwin Baddoo, People's Daily Graphic, 3 November 1992, p. 4.

K. Gyan-Appenteng, Winners and Losers, in: West Africa, 16-22 November 1992, p. 1962. See also Jeff Haynes, Sustainable Democracy in Ghana? Problems and Prospects, in: Third World Quarterly, Vol. 14, No., 3, 1993, pp. 451-467. 
brought by SAP remained indelible in the minds of rural folks who naturally became wary and apprehensive of a threat of instability if he lost. Lastly, some have argued that Rawlings did not win the elections, it was the opposition that lost it. This view is based on the notion that after eleven years in office the anti-Rawlings sentiment in the country could have been milked by any well-organized party that presented a credible alternative to the PNDC. However, according to Gyan Appenteng:

"... the absence of a level playing field in a game in which the ruling junta was player, referee and linesman virtually guaranteed failure for the opposition." ${ }^{41}$

\section{A "Rigged" Presidential Elections?}

The results of the presidential elections were severely questioned by the opposition parties who cried foul and alleged massive "rigging". To them the November 1992 election was the "most controversial in the nation's history" because it was "fraudulently conducted and its result fraudulently procured" ${ }^{42}$. The questioning of the validity of the result led to widespread disturbances in some parts of the country, such as Tamale, Sunyani and Kumasi. The Kumasi riots led to the imposition of a $6 \mathrm{pm}$ to 6 am curfew for six days and was lifted on November 9. In the midst of the confusion over the result that to threaten the security of the country, three bombs set off in various parts of Accra and Tema while the Kwesimintsie constituency chairman of the NDC in the Western Region was burned alive and later died at a London hospital from "third degree" burns. Most people doubted if these frightening acts of violence was the work of the opposition. They saw them as more attempts to give the opposition a bad name, or attempts by some people to take undue advantage of the precarious post-election situation. ${ }^{43}$

On 5 November 1992 the opposition parties called a press conference to provide some proof of the allegations that Rawlings won the elections through "fraudulent manipulations" as well as "systemic rigging of the ballots". It was attended by Adu Boahen of the NPP, Hilla Limann of the PNC, E.A. Erskine of the PHP, and Naa Afarley Sackeyfio, who represented Kwabena Darko of the NIP. Adu Boahen showed the press what he said were 32 fraudulent ballot papers found on a rubbish dump in Kumasi by a school child. 29 out of the 32 ballot papers were thumbprinted in favour of the NDC and bore the INEC stamp number 5363. This, to the opposition, suggested that "someone or a group of persons

41

Ibid.

42 New Patriotic Party, The Stolen Verdict, Accra, NPP, 1993, p. 9.

43

Ad joa Yeboa-Afari, Post-election Thought, in: West Africa, 16-22 November 1992, p. 1963. 
within the Interim National Electoral Commission had been deeply involved in a conspiracy to rig the elections" ${ }^{44}$.

To provide concrete evidence that the elections were rigged, the NPP came out with a publication, The Stolen Verdict, on 7 April 1993. The 89 page publication, plus ten appendices, documents incidents of intimidation, ballot stuffing, impersonation, wrong computation of results, late opening of poll / early or late closing of poll, corrupt and illegal practices / cheating by INEC officials, tampering with ballot boxes and papers, use of defective register, ineligible voters, non-signature of result forms, the dubious role of "revolutionary" organs, security personnel and state-owned media. The Stolen Verdict then ended on a sullen and cautious note:

"The levelling of the electoral playing field is, then, the litmus test of the commitment of Jerry John Rawlings and his colleagues, who remain in charge of the affairs of the nation, to multi-party democracy and free and fair elections. Without a level playing field, elections in this country will continue to produce tragic results of $3^{\text {rd }}$ November 1992 - a stolen verdict." 45

But how justified were the opposition parties in questioning the validity of the results of the elections described by international observers as "free and fair"? To some extent the charges of fraud and irregularities were confirmed externally by the Carter Centre Election Mission which raised serious questions about the dated nature of the voters register, the absence of a reliable and consistent procedure for identifying eligible voters, inconsistency in determining what should be regarded as spoiled ballots, improper sealing of the ballot boxes, the undue influence exerted by some polling agents, and the inability of security personnel to control voters. However, despite these findings, the Carter Centre team observed that:

"... despite the occurrences of serious irregularities in the election process, what we have observed does not lead us to question the validity of the results." 46

The Commonwealth Observer Group also concluded that the election was less than "free and fair", while the errors in the electoral roll were the result of misinformation rather than any attempt to affect the results. ${ }^{47}$ These conclusions seem to suggest that the international community validated the outcome of the elections more than the country's opposition parties. This stance of the international community may be construed as an attitude of "get

44

45

46

47

Ibid. p. 1964.

New Patriotic Party, The Stolen Verdict, op. cit., p. 89.

Report of Carter Centre: Ghana Election Mission, November 6, 1992, p. 1.

Commonwealth Observer Group, Ghana Elections: Interim Statement, November 4, 1992, pp. 1-7. 
on with the experiment" rather than making it a "non-starter" with ominous consequences that might get out of hand.

On 17 November, 1992 the opposition parties, namely, NPP, PNC, NIP and PHP announced their intention to boycott the parliamentary elections (rescheduled for December 29, 1992.to allow for several efforts at mediation) unless the PNDC government acquiesced to compile a new voters register and to issue Ghanaian identification cards. The refusal by the government to meet these demands led to the boycott of the parliamentary elections by the four opposition parties, which came together to form an Inter-Party Coordinating Committee (IPCC).

The boycott had left the field clear for the "Progressive Alliance" of three parties which had all presented Rawlings as their presidential candidate, namely, the NDC, the NCP and the Egle Party. The results of the parliamentary elections were a foregone conclusion and onesided. The NDC won 189 out of the 200 parliamentary seats, while the NCP won 8, Egle Party one and two seats were won by women independent candidates. A regional break down of the results revealed the following picture: Central Region - NCD 16 seats, NCP 1 seat; Volta Region - NDC 18, NCP 1; Upper East - NDC 11 seats, Independent 1 seat; Western - NDC 16, NCP 3; Eastern - NDC 22, NCP 3, Egle 1; Brong Ahafo - NDC 20, Independent 1; Ashanti - NDC won all the 33 seats; Greater Accra - NDC won all the 22 seats; Upper West - NDC all 8 seats; and Northern Region - NDC all 24 seats. $^{48}$

The boycott of the parliamentary elections by the opposition parties naturally affected the turnout. Of the 7,336,346 registered voters, the number that voted in December 29 elections was $2,059,415$, but 23 constituencies returned unopposed candidates. The turnout represented $29 \%$ of voters in the 117 constituencies. In November 3 presidential elections, $3,989,075$ out of $8,255,056$ registered voters voted in all the 200 constituencies with a turnout of $48 \%$. The total votes cast in the parliamentary elections was $51.5 \%$ of votes cast in the presidential elections. 49

\section{Conclusion: The Performance of the Civilian Government and Prospects for the Future}

Ghana's transition to constitutional rule was ridden with controversy at every stage. This was mainly due to the fact that the PNDC dictated the democratization process and its timetable. The timetable seemed to be manipulated so as to enhance the electoral prospects

48 West Africa, 11-17 January 1993, p. 13.
49 Ibid. 
of Rawlings. This naturally created mistrust and distrust in the mind of opposition forces. Certainly, the opposition was aware of the biased nature of the electoral register and how the transition programme was tailored and manipulated to favour Rawlings. Why then did the opposition contest an election that they were bound to lose? Was it misplaced selfconfidence or foolhardiness? It has been argued in some circles that the opposition parties lost the presidential elections because they were not united. This may be wishful thinking in the light of the fact that given the scale of his victory at the polls, there was no guarantee that a united opposition would have made any difference to the outcome.

The boycott of the parliamentary elections had undoubtedly made Ghana a de facto one party state which seems to have some implications for the performance of the NDC government. President Rawlings had on several occasions indicated that the constitution is not sacrosanct and could be amended to make it more workable. Delivering his first sessional address to Parliament on 29 April, 1993, the President emphasized that he would establish regular interaction between the executive and legislature beyond the formal requirements of the Constitution. It is this rapport between the two organs of government that enabled bills to be passed to establish certain institutions, like the Electoral Commission, the Commission on Human Rights and Administrative Justice, the Minerals Commission, the District Assemblies Common Fund and the Commission on Civic Education, within six months of the coming into force of the constitution. Some of these institutions have become the avenues for the redeployment of friends and sympathisers of the PNDC who offered loyal service but could not be accommodated in the mainstream governmental machinery. In both the first and second sessional addresses to Parliament in April 1993 and January 1995, the President made it clear that his government would stick to policy directives chartered by the PNDC government. These include economic liberalization, divestiture of state enterprises, redeployment, provision of basic amenities in the rural areas, the decentralization of the machinery of government and improving productivity and efficiency in the public sector. In line with constitutional provisions, the President has also presented to the Speaker of Parliament in January 1995 the document entitled "Vision 2020", which sets out socio-economic policies programmes to be pursued to better the standard of living of Ghanaians.

The strained relationship between the government and the opposition appears to have been eased with both parties pledging their "readiness to do business" with one another. This cooperative attitude was shown when the NPP presented to the Speaker of Parliament its reply to the 1993 budget statement. The cooperation between government and opposition is reflected in the Inter-Party Committee formed at the auspices of the National Electoral Commission in 1993 to deliberate on the revision of the voters register and the introduction of voters identity cards in preparation of the presidential and parliamentary elections of 1996. Two issues, however, have brought differences between the government and the opposition. The first is the day to hold both elections. While the government insists that the 
two elections should be held on different days, the opposition and the Electoral Commission want the elections to be held the same day. Second is the provision of identity cards to voters. While the government wants the provision of the cards to all citizens and therefore too expensive to be done before 1996, the opposition favours the provision of the cards to those in the urban areas only before the 1996 elections.

Contrary to expectations the NDC-dominated legislature has not been a rubber-stamp judging from the way some MPs approached issues in a non-partisan manner. For instance, when Parliament was discussing portions of the 1993 budget statement, the government proposed to raise the price of petrol from 1,600 cedis to 2,200 cedis. This was vehemently opposed and the government had to revert to the old price. The passage of bills, such as the Serious Fraud Office, Value Added Tax, Public Order, Public Holidays and New Courts, generated a lot of debates and controversies among members of the Legislature Even though these Bills were passed because of the government's majority in Parliament, a couple of substantial changes were made before they became Acts.

The judiciary has also been alive to its responsibilities. It gave three decisions against the executive. First, the Supreme Court had ruled that demonstrations could be held without police permits. Secondly, the Ghana Broadcasting Corporation (GBC) had been ordered to give equal and fair coverage to all the political parties. As a result, the GBC gave full coverage to a news conference organized by the NPP on the 1993 budget in August of the same year. Thirdly, the Supreme Court ruled as unconstitutional the appointments made by the president in August 1993 to the office of District Chief Executive for the 110 districts. As a result of these legal defeats the Attorney-General resigned in April 1994 because of attacks on his competence.

In what appears to be a dress-rehearsal for the 1996 General Elections, the government organized a non-partisan district level elections on March 22, 1994 to elect candidates for 103 DAs, four municipal assemblies and three metropolitan assemblies. In the Northern Region and three other districts in the Volta Region, the elections were postponed because of the ethnic violence that erupted between the Konkombas and Namumbas on February 3, 1994. Although the elections were non-partisan, party caucuses were formed quietly to support one candidate or another. In Nima East, for instance, the NDC rallyed around the incumbent assembly woman, while the PNC and NPP projected candidates to stand for them. Political parties have every reason to support candidates, although it is illegal, because the parties wanted to control the grassroots in order to boost their chances during the 1996 general elections.

From the performance of the NDC government with regards to its adherence to constitutional provisions, one can say that the democratic ethos is gradually being cultivated. The cooling of $f$ of tensions between the government and the opposition parties, even if tempo- 
rarily, may be regarded as a major achievement of the NDC government. In this light, the prospects for the establishment of constitutional rule are brighter than ever. During the second session of Parliament, the Speaker noted that the present Parliament, unlike those of 1969 and 1979, will run its full course. This is because the "jinx that contributed to the fall of the two previous parliaments has been broken" ${ }^{50}$. This is reassuring indeed. One hopes that the hostility and acrimony that characterised the relationship between the government and the opposition parties will give way to lasting credibility and effectiveness on both sides to ensure, preserve and promote the norms of fair play on which all democratic societies are firmly built. If this happens then the legitimacy that Rawlings earnestly tried to seek by returning the country to constitutional rule may have been achieved, even, if partially. As one looks forward to the 1996 elections, what is needed is patience, tolerance and fair play from both the government, the opposition and the general public.

Table 1: Timetable for Return to Constitutional Rule in Ghana

\begin{tabular}{|c|c|}
\hline Date & Event \\
\hline November 1988 - February 1989 & DA Elections \\
\hline 5 July - 9 November 1990 & $\begin{array}{l}\text { Regional Seminars on District Assemblies and Evolving } \\
\text { Democratic Process }\end{array}$ \\
\hline 25 March 1991 & NCD Report on Evolving a True Democracy \\
\hline 5 April 1991 & Presentation of NCD Report to PNDC \\
\hline 17 May 1991 & Establishment of Committee of Experts to Draft Constitution \\
\hline 31 July 1991 & $\begin{array}{l}\text { Committee of Experts presented proposals for a Draft } \\
\text { Constitution to PNDC }\end{array}$ \\
\hline 26 August 1991 & Inauguration of Consultative Assembly \\
\hline 11 November 1991 & Interim National Electoral Commission Law promulgated \\
\hline February 1992 & Interim National Electoral Commission began work \\
\hline 31 March 1992 & Consultative Assembly presented Draft Constitution to PNDC \\
\hline 28 April 1992 & Referendum on Draft Constitution \\
\hline 18 May 1992 & Ban on Politics lifted \\
\hline 30 September 1992 & Nomination closed for Presidential candidates \\
\hline 3 November 1992 & Presidential Elections \\
\hline 29 December 1992 & Parliamentary Elections \\
\hline 7 January 1993 & Inauguration of Fourth Republic \\
\hline
\end{tabular}
11 January 1995. See People's Daily Graphic, 12 January 1995. 


\title{
ABSTRACTS
}

\section{The Structural Adjustment Programme and Democratic Transition in Africa}

\author{
By Said Adejumobi
}

Beginning from the 1980s, Africa witnessed two fundamental changes in her political economy. First, there was a drive towards market economic reforms and liberalisation as couched in the Structural Adjustment Programme. Indeed by 1993 over 40 countries in Africa have adopted one form of adjustment reform or the other with the support of the I.M.F. and the World Bank. Simultaneously, African countries during this period also came under the intense pressure of political reforms. The wave of Democratisation which blew across Eastern Europe and other parts of the world, also gathered momentum in Africa.

The thrust of this paper is to examine the impact of the Structural Adjustment Programme on the process of democratic transition in Africa. The Structural Adjustment Programme, though primarily an economic policy, also has a political logic. The political essence of it lies in redefining the role and scope of the State, the sphere of political competition and struggles and the nature of accumulation within the State.

Also, the socioeconomic impact, which the various elements of the policy (vis devaluation of national currencies, trade liberalisation, subsidy withdrawal on essential services, trade liberalisation and so on) engender, has serious consequences for the process of democratisation on the continent. Undoubtedly, the socioeconomic base of democratic reforms in Africa is being presently defined by the Structural Adjustment Programme.

\section{Ghana's Return to Constitutional Rule under the Provisional National Defence Council}

By Joseph R.A. Ayee

The Provisional National Defence Council (PNDC), the longest regime that ever ruled Ghana during the post-colonial period (having been in power from 31 December 1981 to 6 January 1993), returned the country to constitutional rule after twelve years of authoritarian rule on 7 January 1993 with the inauguration of the Fourth Republic. The inauguration was preceded by the holding of presidential and parliamentary elections on 3 November 1992 and 29 December 1992 respectively. 
The paper examines the formulation and implementation of the programme to return the country to constitutional rule, with special emphasis on the problems encountered and their implications for the building of a democratic culture in Ghana. First, it examines the design of the programme to return the country to constitutional rule. It then proceeds to analyze the strategies and procedures devised for the realization of the programme. Lastly, the paper discusses the elections, the performance of the civilian government and prospects for the future.

\title{
Political Reform in Japan
}

\section{By Heinrich Kreft}

The author analyses the decline of the Liberal Democratic Party (LDP) in the wake of the inauguration of the first non-LDP government in 1993. Corruption and scandals made a political reform inevitable, but the opposition parties (mainly the Socialist Party) because of their internal weaknesses did not pose a serious challenge to the ruling LDP. Political reform became possible only when the LDP split and its reform-minded faction formed a coalition with smaller conservative parties and the socialists. After fierce battles with the LDP the new government finally succeeded in reforming the electoral system for the Lower House. Under the new law multi-member constituencies will be abandoned for the next election, due by 1997. Candidates for parliament will run for 300 single-member constituencies; 200 additional seats are filled by proportional representation. This reform could fundamentally change Japan's political landscape. Even though the reform-government of Prime Minister Hosokawa and its successor had been replaced already in 1994 by a coalition of the LDP and the Socialist Party, the reform process was only slowed down but not halted. The next parliamentary elections will thus be crucial for the political reform process in Japan.

\section{The Granting of Amnesty for Human Rights Violations in Latin America from an International Criminal Court Perspective}

\author{
By Kai Ambos
}

One of the most frequent reasons for the impunity (impunidad) of human rights violations in Latin America is the granting of amnesty in favor of perpetrators - who are often mem- 